associated with an infectious condition of the wool produeing "weather stain" and it is prevalent following "excessive rains and humid conditions generally". Attacks on the back are not uncommon in this country; in fact, they were especially prevalent in North Wales during the dry summers of 1933 and 1934, infestation usually beginning in the region between the shoulder-blades. Clearly, the humidity at this spot must sometimes become abnormally high, perhaps owing to excessive sweating. The humidity at the wool base was occasionally found to be higher in this region than elsewhere on the back.

We have, therefore, concluded that in Great Britain, whether fæces, urine or sweat be responsible, it is the moisture in each instance which permits the establishment of sheep maggots.

These results will shortly be published in detail elsewhere.

W. Maldwyn Davies.

R. P. HoBson.

Department of Agricultural Zoology, School of Agriculture,

University College of North Wales, Bangor. Dec. 4.

${ }^{2}$ Nature, 134, 813, Nov. 24, 1934.

\section{Mutations and the Ageing of Seeds}

M. NAVASHIN ${ }^{1}$ and his co-workers reported in a series of papers that plants produced from old seeds in Crepis show a great percentage of 'mutations'. Similar observations were reported by Cartledge and Blakeslee $^{2}$ and by Peto ${ }^{3}$ in Ameriea working with various plants. They confirmed the results found by Navashin and his co-workers. All these authors state that Navashin made this discovery. Hugo de Vries, however, in his "Mutationstheorie" (1901)4, reported that in one case five-year old seeds from Oenothera gave 40 per cent instead of 5 per cent mutations (p. 185). He interpreted this phenomenon by postulating a longer viability of the 'mutated' seeds (p. 186).

More extensive studies on the ageing of the seeds in Oenothera were reported by Nils Heribert Nilsson $(1931)^{5}$. He summarised his observations in a table and from the results obtained he drew the following conclusion: "Mit dem Alter des Samens, also mit der herabgesetzten Keimfähigkeit, geht das Ansteigen des Mutationsprozent ausgesprochen parallel" (p. $326)$.

Recent investigations (see, Cleland, Darlington, Gates, Renner, Oehlkers, and others) showed that some of the mutations in Oenothera are due to segmental interchanges between non-homologous parts of the chromosomes. Consequently the mutations reported by $\mathrm{H}$. de Vries and $\mathrm{N}$. Heribert Nilsson are obviously due to chromosomal alterations. Chromosomal alterations (but not gene mutations) were reported by Navashin too, that is, Navashin confirmed cytologically the observations reported by de Vries and Heribert Nilsson.

Institute of Genetics,

Dontcho KostofF.

Academy of Sciences of U.S.S.R., Moscow.

' Navashin, Nature, 131, 436 ; 132, 482 ; 1933. Planta :20, 233 ; 1933.

Cartledge and Blakeslee, Science, 78, 523; 1933. Proc. Nat. Acod. Sci., 20 ; 1934.

"Peto, Canad. J. Res., 9, $261 ; 1933$

H. de Vries, "Mutationstheorie", 1901 ; pp. 185, 186

\section{Vitamin $B_{1}$ and Blue Fluorescent Compounds}

Fluorescence in ultra-violet light (screened by Wood's glass) is not a property of vitamin $\mathrm{B}_{1}$; but I have found that the purest preparations in our possession (method of Kinnersley, O'Brien and Peters, $1933^{1}$ ) can be converted by oxidation in aqueous solution into substances showing an intense sky-blue fluorescence.

Blue fluorescent compounds are stated to arise as breakdown products of the yellow fluorescent flavins (Kuhn, et al. ${ }^{2}$ ); hence the Bence Jones 'quinoidine' substances in yeast extracts (Kinnersley, Peters and Squires $^{3}$ ) can originate from vitamin $B_{I}$ as well as from vitamin $B_{2}$. Arising from my observation upon vitamin $B_{1}$, it seems to be possible for the first time to postulate a relation between vitamin $B_{1}$ and the pyrimidazine group. In this connexion it is interesting to note that the empirical composition $\mathrm{C}_{12} \mathrm{H}_{16} \mathrm{ON}_{4} \mathrm{~S}$ of vitamin $\mathrm{B}_{1}$ (Windaus et al. ${ }^{4}$, Holiday et $a l .^{5}$ ) corresponds with that of a thio-hexahydro lumichrome (lumichrome $\mathrm{C}_{12} \mathrm{H}_{10} \mathrm{O}_{2} \mathrm{~N}_{4}$ ). The hydrogenation of the azine or benzene rings may account for the strength of the vitamin as a base and for its high water solubility.

The several lines of investigation thus indicated are being actively pursued by ourselves and colleagues, though it is admittedly difficult to reconcile our working hypothesis with the formation of the par. ticular degradation products of vitamin $B_{1}$ recently described by Windaus, Tschesche and Grewe ${ }^{6}$. So far, it has not been found possible to replace vitamin $B_{1}$ with flavin in the specific respiration of avitaminous brain tissue, which is catalysed by vitamin $B_{1}{ }^{7}$.

Department of Biochemistry, Rudolph A. Peters.

\section{Oxford.}

Dec. 23.

1 Biochem. J., 27, $232 ; 1933$.

Kuhn, Rudy and Wagner-Jauregg, Ber. deut, chem. Ges., 68, 1950 ; 1933. See also Stern and Holiday, Ber, 67, 1442, and Karrer Salomon, Schopf, Schlittler and Fritzch, Helvet. Chem. Acta, 17, $1010 ; 1934$ ${ }^{3}$ Biochem. J., 19, 404 ; 1925. See also von Euler and Adler, $Z$ physiol. Chem., 228, 1 ; 1934

Windaus, Tschesche and Ruhkopf, Nach. Ges. Wissen. Gottingen, 111,$343 ; 1932$.

${ }^{6}$ Holiday, Kinnersley, $O^{\prime} B r i e n$ and Peters, $J$. Soc. Chem. Ind., 53, 024 ; 1934.

- Windaus, Tsehesche and Grewe, Z. physiol. Chem, 228, 27; 1934 - Passmore, Peters and Sinclair, Biochem. J., 27, 843; 1933.

\section{Testing for Unconsciousness After an Electric Shock}

IT has been definitely proved that the tests of consciousness used in chloroform anæsthesia cannot safely be assumed to be valid in the case of an animal or person who has been immobilised as a result of an electric stimulation of the brain. The matter is of great importance because, as a result of the Slaughter of Animals Act, electric immobilisation is being extensively used in the slanghter-house as an alleged anæsthetic; and its use for operations, both veterinary and experimental, has been proposed.

The object of this letter is to point out that there exists a strong tendency to stifle inquiry into this unsettled question, and to discourage further investigation by making statements which imply that electrolethalling has been proved to cause genuine anæsthesia. It is not difficult to explain this tendeney to brush aside unsettled questions, for there are strong motives for desiring to believe that electrolethalling, as practised in the slaughter-house, is humane. Moreover, vested interests have grown up around the practice, and humanitarians who have 